\title{
ANALYSIS OF INTEGRAL BRIDGE FOR DEAD LOAD AND MOVING LOADS
}

\author{
M.P.Bastwadkar ${ }^{1}$, S.S.Manekari ${ }^{2}$ \\ ${ }^{1}$ Asst. Professor, Civil Engineering Department, JSPM'S Imperial College Of Engineering And Research, Wagholi, \\ Pune, Maharashtra, India \\ ${ }^{2}$ Asst. Professor, Civil Engineering Department, JSPM'S Imperial College Of Engineering And Research, Wagholi, \\ Pune, Maharashtra, India
}

\begin{abstract}
The construction of Integral Bridges is rapidly growing throughout the world. This is mainly due to elimination of problematic and expensive expansion joints. In the Integral Bridge the abutments are monolithically connected with superstructure and for the piers a monolithic or simply supported connection is made with the superstructure. In this study the behavior of Integral Bridge of three different spans are studied by finite-element analyses under dead load, Moving loads(IRC vehicle load). Results showed that two span Integral Bridge is suitable in structural, economy and construction point of view
\end{abstract}

Keywords: Superstructure, Integral , bearings , abutments, monolithic etc...

$* * *$

\section{INTRODUCTION}

Integral Abutment Bridges can be described as bridges generally built their superstructures integral with the abutments, without expansion or contraction joints for the entire length of the superstructure. The structural system offered by bridges made integral between superstructure and abutments can provide structural efficiencies as well as enables the elimination of bearings and expansion joints. In some circumstances the durability of the bridge is improved and maintenance costs reduced.

These bridges are single span or multispan bridges. The abutments, being cast integral with the superstructure so as to avoid the expansion joints and movement bearings that otherwise require regular maintenance. The piers for Integral Abutment Bridges may be constructed either integrally with or independently .

The benefits of Integral Bridges are principally the elimination of expansion joints and bearings, leading to simpler structures that are easier and less expensive to maintain.

\section{LITERATURE REVIEW}

"Simplified model for Computer-Aided Analysis of Integral Bridges" by Murat Dicleli[2]

This paper presents a computer-aided approach for the design of Integral-Abutment Bridges. An analysis procedure and a simplified structure model are proposed for the design of Integral-Abutment Bridges considering their actual behavior and load distribution among their various components. A computer program, for the analysis of Integral-Abutment Bridges, has been developed using the proposed analysis procedure and structure model. The program is capable of analyzing an Integral-Abutment Bridge for each construction stage and carrying the effects of applied loads on the structure members from a previous construction stage to the next. The proposed analysis methods and structure models are compared with the conventional analysis method and structure model currently used by many structural Engineers for the design of IntegralAbutment Bridges. The benefits of using the proposed analysis method and simplified structure model for the design of Integral Abutment Bridges are discussed. It was concluded that it may be possible to obtain more sound and economical designs for Integral-Abutment Bridges using the proposed analysis method and structure model.

\section{FINITE ELEMENT MODELING}

Every structural analysis is done by using mathematical models. The quality of the results obtained from such models depends on the quality of the assumptions and generalizations that are considered in each model.

Modeling of Integral Bridges is done with the assumption that the abutments are completely rigid with the deck slab. The criteria on which Integral Bridges are modeled in SAP2000v14.The deck is Integral with Abutments and Piers

\subsection{Model Description of Bridges}

An Integral Bridge of length $50 \mathrm{~m}$ is adopted for this study. Three bridge models are prepared having single span, two span and three spans. Single span bridge is of 50m length, two spans of length $25 \mathrm{~m}$ each and three spans of 16.67 each. The width of the bridge is taken $10.5 \mathrm{~m}$. With two lanes of width $3.75 \mathrm{~m}$ each. The intermediate piers constitute of three columns, over which a pier cap is provided to rest the main longitudinal girders. The abutment walls and pier columns are considered fixed at the base. Three steel girders Integral 
Bridge has modeled, in which the deck is modeled as reinforced concrete deck. Three Integral Bridge models are selected for this study. Details of the bridge and constituent material are given below.

Table -1: Details of the bridge and constituent material

\begin{tabular}{|l|l|}
\hline Deck slab Thickness & $250 \mathrm{~mm}$ \\
\hline No of main girders & 5 \\
\hline Abutment Dimensions & $10.5 \mathrm{~m} \mathrm{X} \mathrm{1m} \mathrm{X} \mathrm{3m}$ \\
\hline Pier column diameter & $1 \mathrm{~m}$ \\
\hline Pier cap dimension & $10 \mathrm{~m} \mathrm{X} \mathrm{1m} \mathrm{X} \mathrm{1.2m}$ \\
\hline Pier height & $8 \mathrm{~m}$ \\
\hline Grade of Concrete & $\mathrm{M} \mathrm{30}$ \\
\hline Grade of Steel & $\mathrm{Fe} \mathrm{415}$ \\
\hline Main girder (steel section) & $\mathrm{W} 36 \times 160$ \\
\hline
\end{tabular}

\subsection{Element Family for Modeling}

\subsubsection{The Shell Element}

The four-noded shell elements are used to model the bridge deck.Fig.1 The shell element is used to model shell, membrane and plate behavior in planar and threedimensional structures. The shell element/object is one type of area object. The Shell element is a three- or four-node formulation that combines separate membrane and platebending behavior. The four-joint element does not have to be planar. The membrane behavior uses an isoperimetric formulation that includes translational in-plane stiffness components and a rotational stiffness component in the direction normal to the plane of the element. The plate bending behavior includes two-way, out-of-plane, plate rotational stiffness components and a translational stiffness component in the direction normal to the plane of the element.

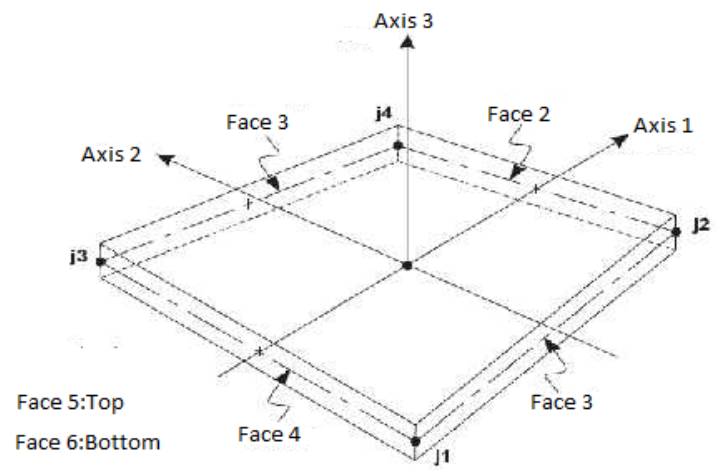

Fig -1: Four-node Quadrilateral Shell Element

\subsubsection{The Frame Element}

Two noded beam elements are used to model the reinforced concrete abutment, piers and pier cap. The Frame element is used to model beam, column, truss, and brace behavior in planar and three-dimensional structures. The Frame element uses a general, three-dimensional, beam-column formulation which includes the effects of biaxial bending, torsion, axial deformation, and bi-axial shear deformations. The Frame element activates all six degrees of freedom at both of its connected joints. Element internal forces are produced at the ends of each element. Fig. 2 Frame element internal forces and moments
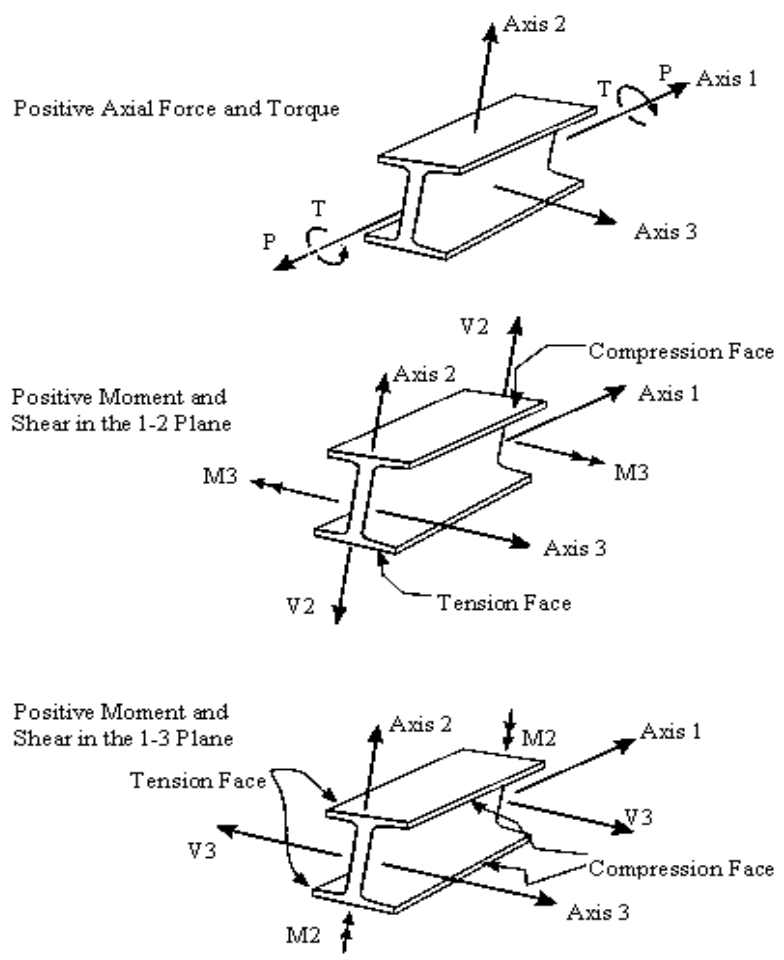

Fig -2.: Frame Element Internal Forces and Moments

\subsubsection{Deck Slab and Girder}

The Deck and the Girder are accounted by Rigid Links. Deck slab is modeled by quadrilateral shell element, which couples bending with membrane action. Longitudinal girders and diaphragm are modeled as frame element. The deck and girder are placed at their vertical location of the centroid respectively. The composite action between the deck and girder is effected by the rigid links. Fig. 3 showing the composite modeling of deck slab and longitudinal girder.

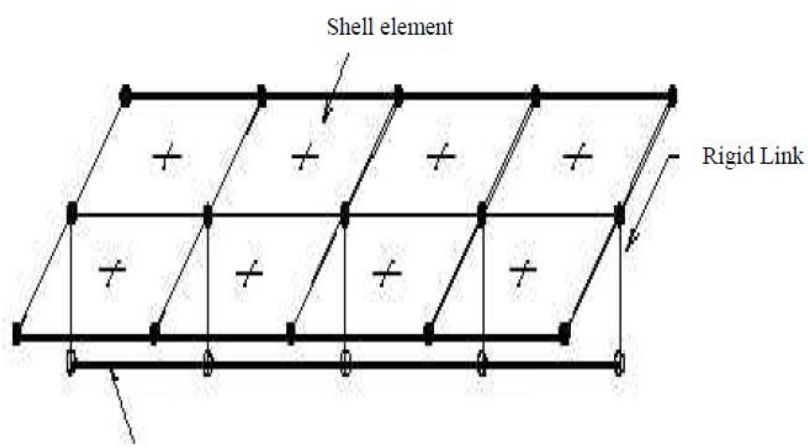

Girder (Beam element)

Fig -3 Composite Modeling of Deck Slab and Girders

\subsubsection{Material Properties}

The reinforced concrete material used for the bridge deck is assumed to be elastic plastic. The modulus of elasticity of M30 grade of concrete the design young's Modulus (E) 
value is considered is $30.5 \times 10^{6} \mathrm{kN} / \mathrm{m}^{2}$ for characteristic strength of concrete is $30000 \mathrm{kN} / \mathrm{m}^{2}$. The concrete and steel material properties are taken from IRC21:2000. Steel Ibeams are used to model the steel beams with a modulus of elasticity of $2.0 \times 10^{8} \mathrm{kN} / \mathrm{m}^{2}$.

\subsubsection{D Views of all Models}

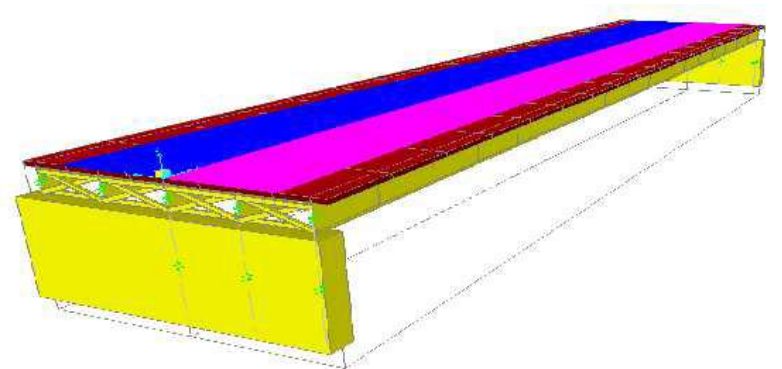

Fig -4: 3-D View of Single Span Integral Bridge

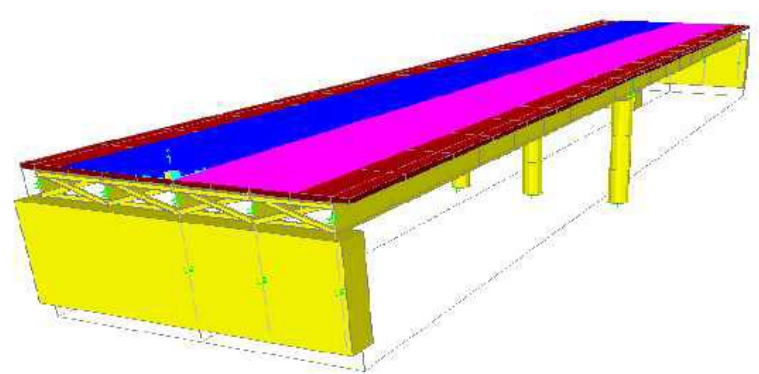

Fig -5: 3-D View of Two Span Integral Bridge

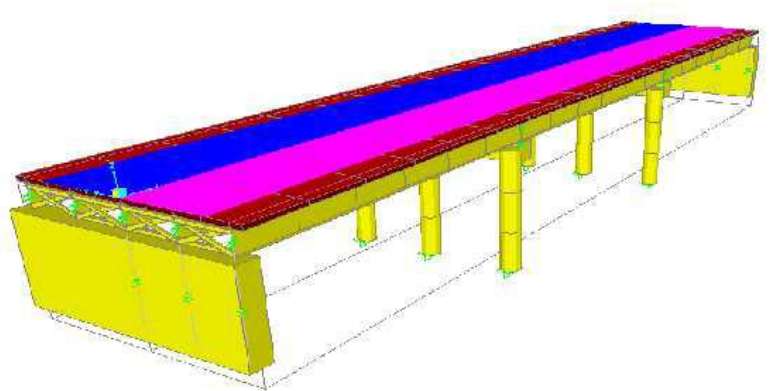

Fig -6: 3-D View of Three Span Integral Bridge

The above three finite element models, i.e. Fig 4,5,6 are developed to present the characteristics of the analyses:

1) Dead loading

2) Live loading ie.IRC70R, IRC Class A loading

All finite element models were developed using the software SAP 2000v14.

\section{RESULTS AND DISCUSSION}

In the present work, the variation of bending moments(BM), shear forces(SF), axial forces and the extreme fiber stresses in the superstructure (deck slab) for different spans have been studied. Bridges are modeled and analyzed for dead load, live load (IRC70R, IRC class A). The effect of these loading on the parameters with respect to max positive BM, maximum negative $\mathrm{BM}$ in the superstructure (deck slab), max positive SF, maximum negative $\mathrm{SF}$, maximum axial force in the deck and extreme fiber stresses at top and bottom of deck slab has been observed and discussed.

\subsection{Effect of Dead Load on Super Structure}

The variation in BM, SF, axial forces and extreme fibre stresses in the superstructure due dead loads only for the three different spans $(50 \mathrm{~m}, 25 \mathrm{~m} \& 16.67 \mathrm{~m})$ are represented in the form of graphs below.

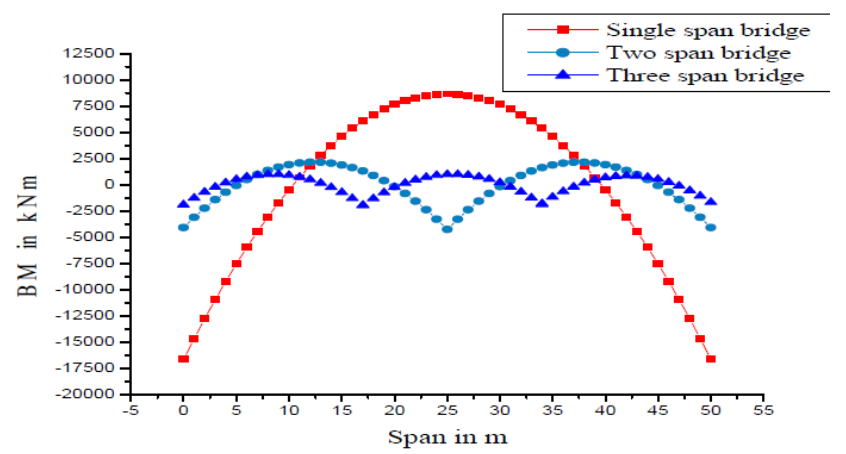

Fig-7 BM variation in Superstructure due to dead load for three different spans

\subsection{Bending Moment due to Dead Load}

From Fig. 7. BM variation in superstructure (deck slab) due to dead loads is represented for three different spans. The $\mathrm{BM}$ is maximum for single span $(50 \mathrm{~m})$, for two spans $(25 \mathrm{~m}$ each) BM reduces upto $75 \%$ and for three spans $(16.67 \mathrm{~m}$ each) BM reduces upto $88 \%$.

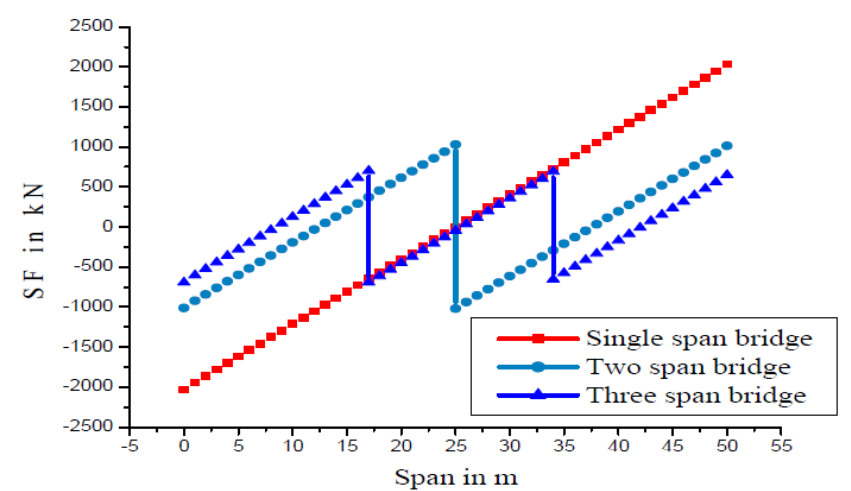

Fig-8 SF variation in Superstructure due to dead load for three different spans.

\subsection{Shear Force due to Dead Load}

From Fig. 8. SF variation in superstructure (deck slab) due to dead loads is represented for three different spans. The SF is maximum for single span $(50 \mathrm{~m})$, for two spans $(25 \mathrm{~m}$ each) SF reduces upto $50 \%$ and for three spans $(16.67 \mathrm{~m}$ each) SF reduces upto $66 \%$. 


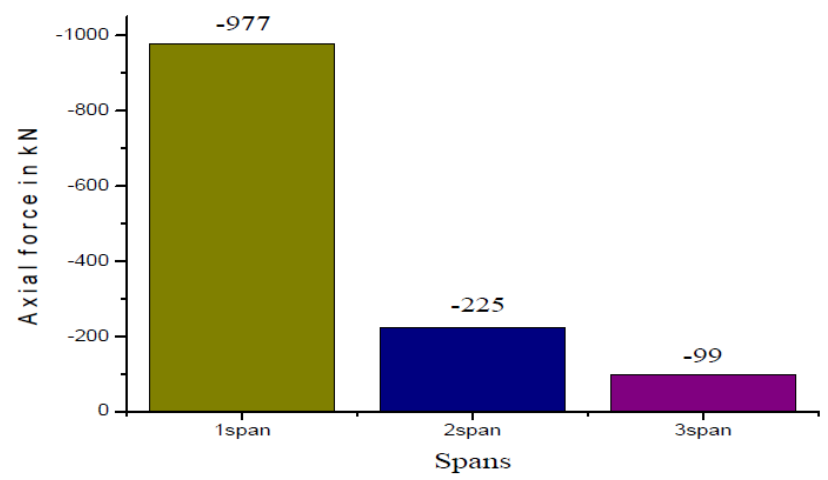

Fig-9 Axial force in Superstructure due to dead load for three different spans.

\subsection{Axial Force due to Dead Load}

From Fig. 9. Axial force variation in superstructure due to dead loads is represented for three different spans. The Axial force axial force is maximum for single span $(50 \mathrm{~m})$, for two spans (25m each) the axial force reduces upto $77 \%$ and for three spans $(16.67 \mathrm{~m}$ each) the axial force reduces upto $90 \%$.

Table -2 Maximum positive and negative BM and SF due to dead load for three different spans.

\begin{tabular}{|l|l|l|l|l|l|}
\hline $\begin{array}{l}\text { Sr. } \\
\text { No. }\end{array}$ & $\begin{array}{l}\text { Bridg } \\
\text { e } \\
\text { spans }\end{array}$ & $\begin{array}{l}\text { Max. } \\
\text { positi } \\
\text { ve } \\
\text { BM in } \\
\text { kNm }\end{array}$ & $\begin{array}{l}\text { Max. } \\
\text { Negative } \\
\text { BM in } \\
\text { kNm }\end{array}$ & $\begin{array}{l}\text { Max. } \\
\text { positive } \\
\text { SF in } \\
\text { kN }\end{array}$ & $\begin{array}{l}\text { Max. } \\
\text { negativ } \\
\text { e } \\
\text { SF in } \\
\text { kN }\end{array}$ \\
\hline 1 & $\begin{array}{l}\text { Single } \\
\text { Span }\end{array}$ & 8662 & -16640 & 2032 & -2032 \\
\hline 2 & $\begin{array}{l}\text { Two } \\
\text { Span }\end{array}$ & 2162 & -4064 & 1028 & -1019 \\
\hline 3 & $\begin{array}{l}\text { Three } \\
\text { Span }\end{array}$ & 1005 & -1959 & 700 & -693 \\
\hline
\end{tabular}

Table -3 Maximum Axial force due to dead load for three different spans

\begin{tabular}{|l|l|l|}
\hline Sr.No. & Bridge spans & $\begin{array}{l}\text { Max.Axial force in } \\
\text { kN }\end{array}$ \\
\hline 1 & Single Span & -977 \\
\hline 2 & Two Span & -225 \\
\hline 3 & Three Span & -99 \\
\hline
\end{tabular}

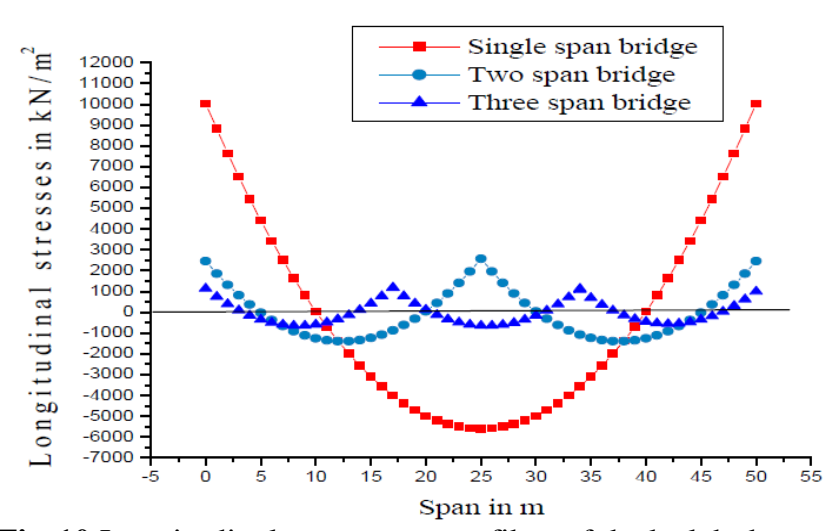

Fig-10 Longitudinal stresses at top fibre of deck slab due to dead load for three different spans.

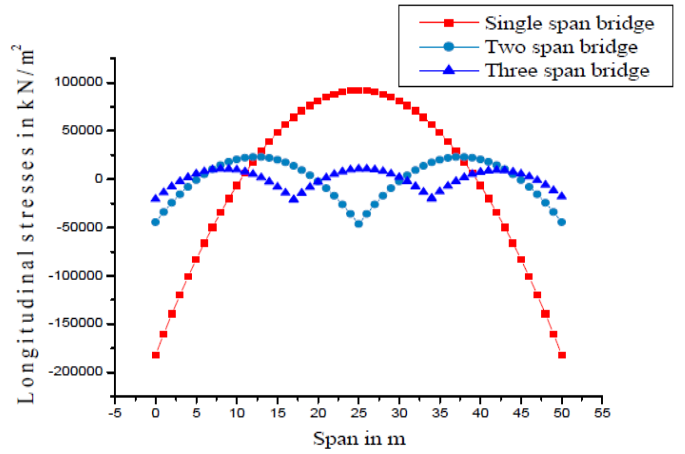

Fig. -11 Longitudinal stresses at bottom fibre of deck slab due to dead load for three different spans

\subsection{Longitudinal Extreme Fiber Stress Results}

From Fig.10, Longitudinal extreme top fiber stress variation in superstructure due to dead loads is represented for three different spans. The longitudinal extreme top fiber stresses are maximum for single span $(50 \mathrm{~m})$, for two spans $(25 \mathrm{~m}$ each) it reduces upto $75 \%$ and for three spans $(16.67 \mathrm{~m}$ each) it reduces upto $89 \%$. From Fig.11, Longitudinal bottom fiber stress variation in superstructure due to dead loads is represented for three different spans. The longitudinal bottom fiber stresses are maximum for single span $(50 \mathrm{~m})$, for two spans (25m each) it reduces upto $75 \%$ and for three spans $(16.67 \mathrm{~m}$ each) it reduces upto $89 \%$.

Table-4 Max. positive and negative longitudinal stresses due to dead load for three different spans

\begin{tabular}{|l|l|l|l|l|}
\hline & $\begin{array}{l}\text { Max. } \\
\text { positive } \\
\text { longitudi } \\
\text { nal } \\
\text { stresses at } \\
\text { top } \\
\text { Bibre of } \\
\text { spans } \\
\text { deck } \\
\text { slab in } \\
\text { kN/m }\end{array}$ & $\begin{array}{l}\text { Max. } \\
\text { negative } \\
\text { longitudi } \\
\text { nal } \\
\text { stresses at } \\
\text { top } \\
\text { fibre of } \\
\text { deck } \\
\text { slab in } \\
\text { kN/m }\end{array}$ & $\begin{array}{l}\text { Max. } \\
\text { positive } \\
\text { longitudi } \\
\text { nal } \\
\text { stresses at } \\
\text { bottom } \\
\text { fibre } \\
\text { of deck } \\
\text { slab in } \\
\text { kN/m }\end{array}$ & $\begin{array}{l}\text { in } \\
\text { negative } \\
\text { longitudi } \\
\text { nal } \\
\text { stresses } \\
\text { at } \\
\text { bottom } \\
\text { fibre } \\
\text { of deck } \\
\text { slab } \\
\text { inkN/m }\end{array}$ \\
\hline $\begin{array}{l}\text { Single } \\
\text { Span }\end{array}$ & 10038 \\
\hline $\begin{array}{l}\text { Two } \\
\text { Span }\end{array}$ & 2569 & -5598 & 92153 & -181728 \\
\hline $\begin{array}{l}\text { Three } \\
\text { Span }\end{array}$ & 1185 & -646 & 10722 & -21374 \\
\hline
\end{tabular}

\subsection{Live Load (IRC70R truck) Effects on Integral}

\section{Bridges for Superstructure}

In accordance to IRC, two classes of live load consisting of (i)IRC-70R and (ii) IRC-ClassA have been considered for the $7.5 \mathrm{~m}$ width of carriage way (IRC6:2010). In IRC-70R both tracked and wheeled vehicles are considered. Since the maximum live load effects occur due to IRC70R wheeled (truck) vehicle, only these results are presented in Fig. 12 to 14 below: 


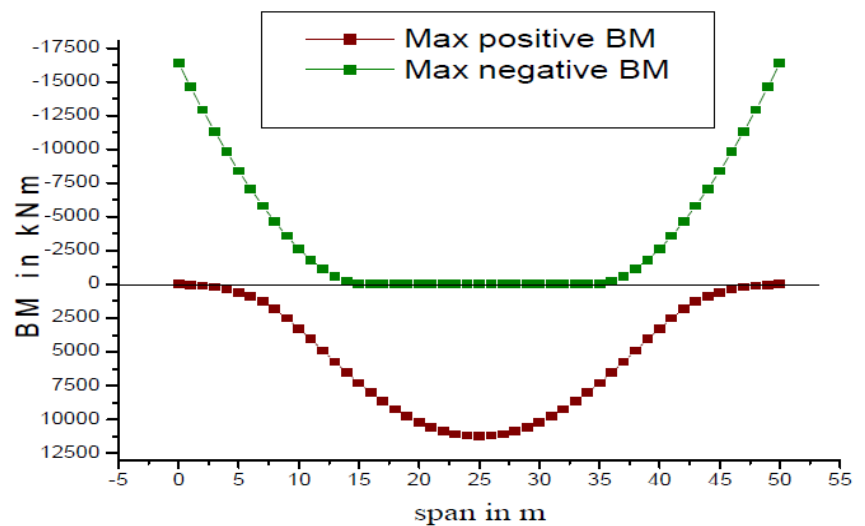

Fig. -12 Variation in BM in superstructure due to IRC-70R wheeled vehicle for single span

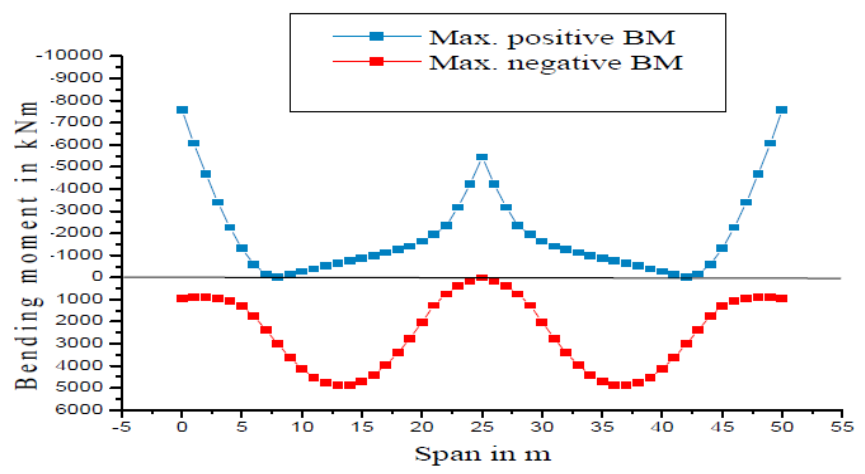

Fig. -13 Variation in BM in superstructure due to IRC-70R wheeled vehicle for two span

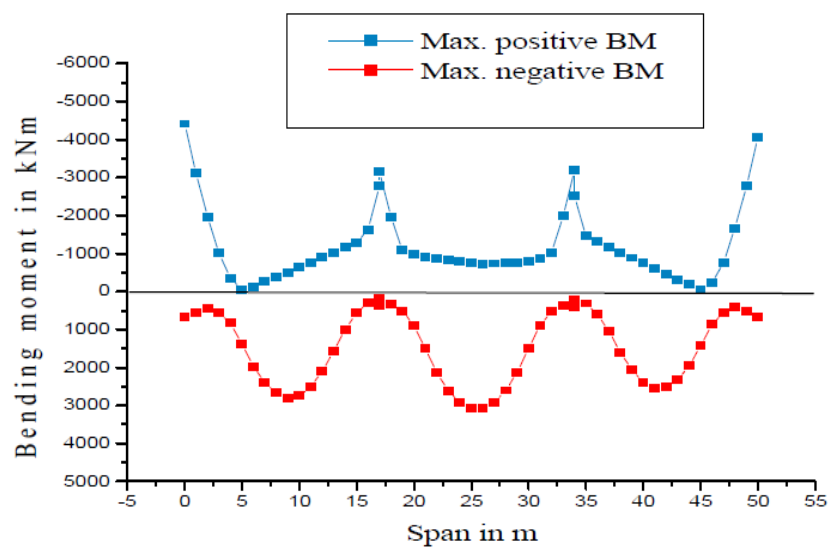

Fig. -14 Variation in BM in superstructure due to IRC-70R wheeled vehicle for two span.

\subsection{Bending Moment due to Live Load (IRC70R Wheeled)}

Fig. 12 to 14, shows BM results due to live load (IRC70R truck) on Integral Bridge superstructure and variation for three different spans. Result shows that the positive BM for single span $(50 \mathrm{~m})$ is maximum, for two spans $(25 \mathrm{~m}$ each) it reduces upto $57 \%$ and for three spans $(16.67 \mathrm{~m}$ each) it reduces upto $73 \%$. Also, the negative $\mathrm{BM}$ for single span (50m) is maximum, for two spans (25m each) it reduces upto $54 \%$ and for three spans $(16.67 \mathrm{~m}$ each) it reduces upto $73 \%$.

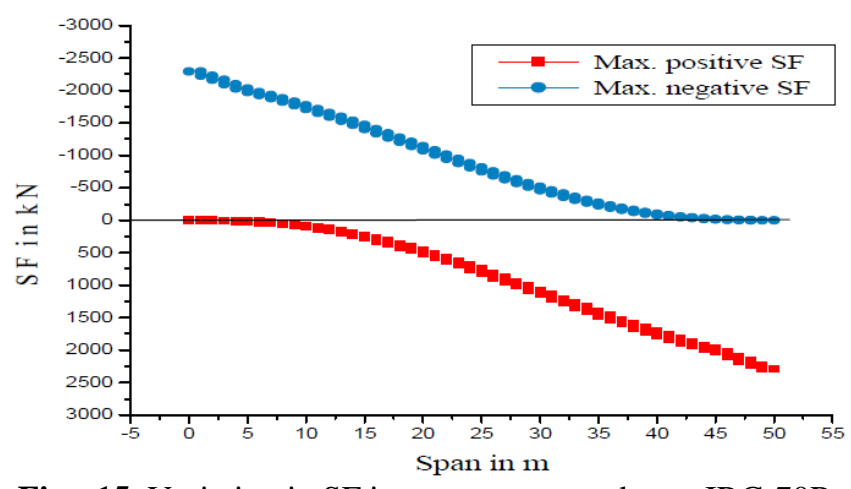

Fig. -15 Variation in SF in superstructure due to IRC-70R wheeled vehicle for single span.

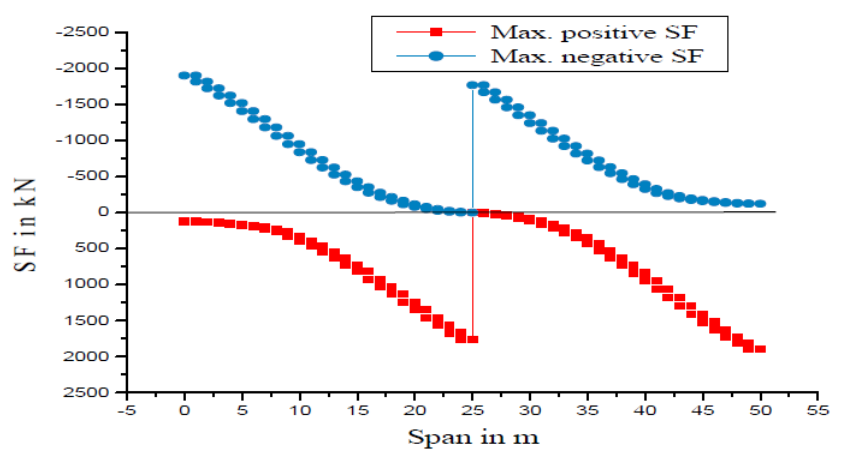

Fig. -16 Variation in SF in superstructure due to IRC-70R wheeled vehicle for two span.

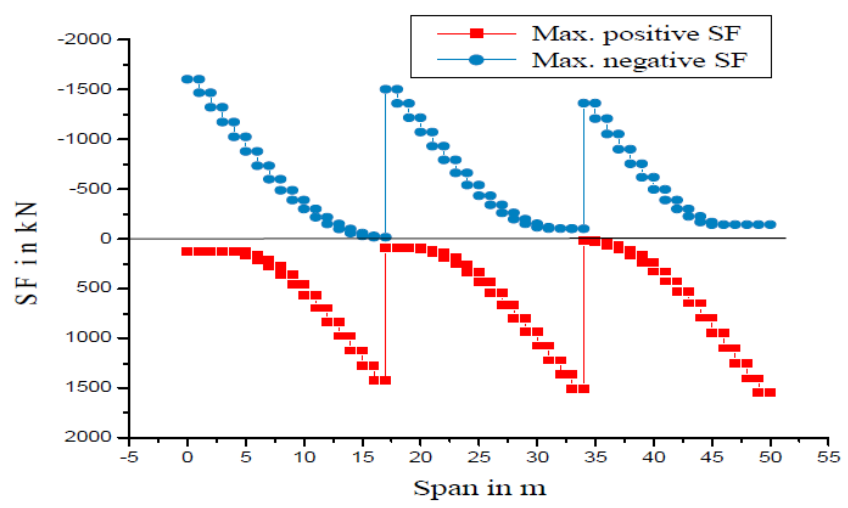

Fig. -17. Variation in SF in superstructure due to IRC-70R wheeled vehicle for three span.

\subsection{Shear Force due to Live Load (IRC70R Wheeled)}

Fig. 15 to 17., shows SF results due to live load (IRC70R wheeled vehicle) on superstructure and variation for three different spans. Result shows that the positive SF for single span $(50 \mathrm{~m})$ is maximum, for two spans (25m each) it reduces upto $17 \%$ and for three spans $(16.67 \mathrm{~m}$ each) it reduces upto $33 \%$. Also, the negative SF for single span $(50 \mathrm{~m})$ is maximum, for two spans $(25 \mathrm{~m}$ each) it reduces upto $17 \%$ and for three spans $(16.67 \mathrm{~m}$ each) it reduces upto $30 \%$. 


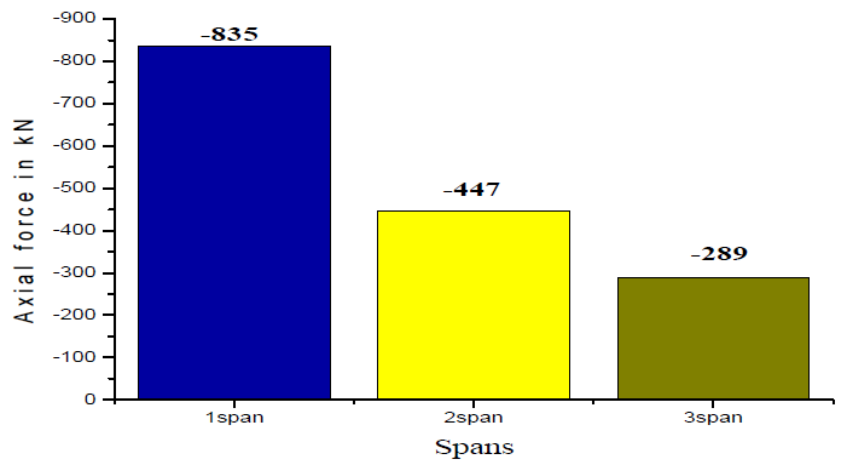

Fig. -18 Variation in axial force in superstructure due to IRC-70R wheeled vehicle for different spans.

\subsection{Axial Force Results due to Live Load (IRC70R}

\section{Wheeled)}

Fig. 18 Shows Axial force results due to live load (IRC70R wheeled vehicle) on superstructure and variation for three different spans. Result shows, the axial force is maximum for single span $(50 \mathrm{~m})$, for two spans $(25 \mathrm{~m}$ each) the axial force reduces upto $47 \%$ and for three spans $(16.67 \mathrm{~m}$ each) the axial force reduces upto $65 \%$

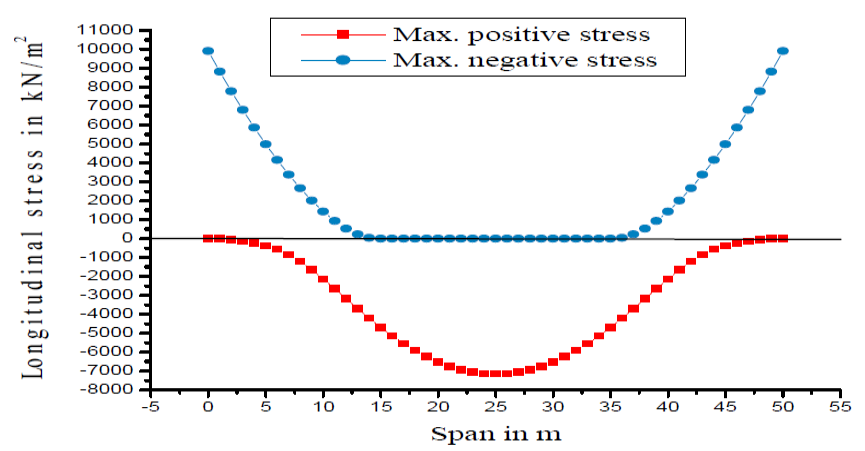

Fig. -19 Variation in longitudinal stresses at top fiber of superstructure due to IRC-70R wheeled vehicle for single span.

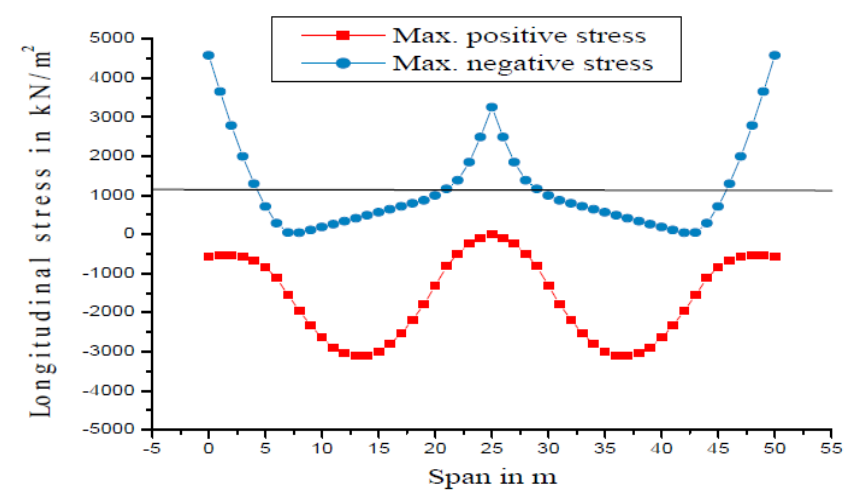

Fig. -20 Variation in longitudinal stresses at top fiber of uperstructure due to IRC-70R wheeled vehicle for two span.

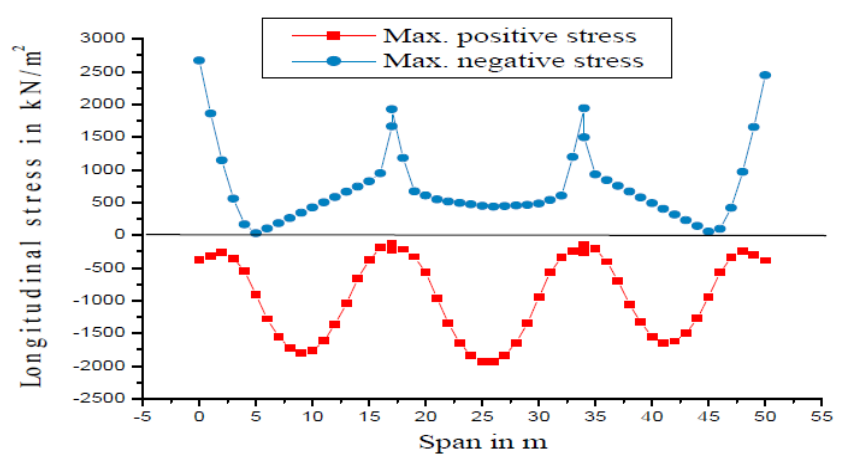

Fig. -21. Variation in longitudinal stresses at top fiber of superstructure due to IRC-70R wheeled vehicle for three span.

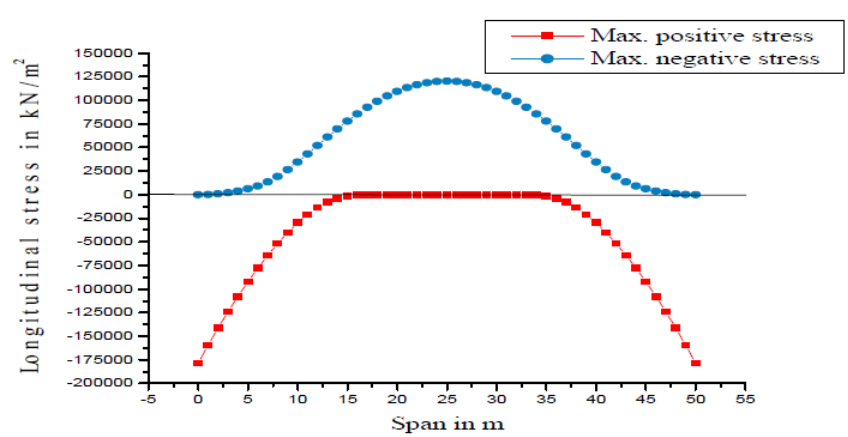

Fig. -22. Variation in longitudinal stresses at bottom fibre of superstructure due to IRC-70R wheeled vehicle for single span.

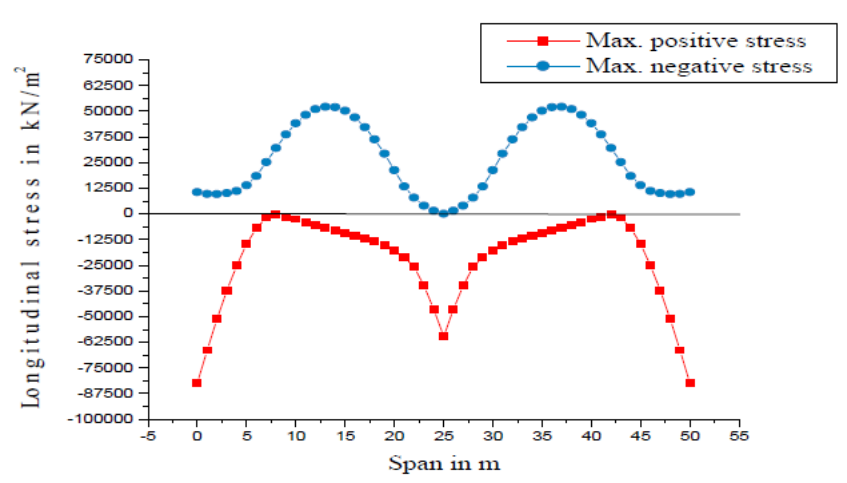

Fig. -23 Variation in longitudinal stresses at bottom fibre of superstructure due to IRC-70R wheeled vehicle for two span.

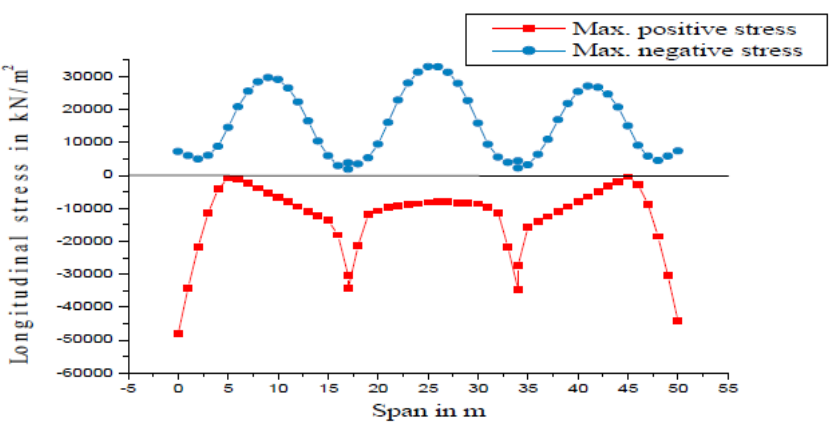

Fig. -24 Variation in longitudinal stresses at bottom fibre of superstructure due to IRC-70R wheeled vehicle for three span. 


\subsection{Longitudinal Fiber Stress Results due to Live}

\section{Load (IRC70R Wheeled)}

Fig. 19 to 21 shows maximum positive longitudinal top fiber stress results due to live load (IRC70R wheeled vehicle) on superstructure shows the variation for three different spans. Result shows, the maximum positive longitudinal top fiber stresses are Table -3 Maximum positive and negative BM, SF due to IRC70R wheeled vehicle load for three different spans maximum for single span $(50 \mathrm{~m})$, for two spans $(25 \mathrm{~m}$ each) it reduces upto $54 \%$ and for three spans $(16.67 \mathrm{~m}$ each) it reduces upto $70 \%$.

Also the maximum negative longitudinal top fiber stresses are maximum for single span $(50 \mathrm{~m})$, for two spans $(25 \mathrm{~m}$ each) it reduces upto $57 \%$ and for three spans $(16.67 \mathrm{~m}$ each) it reduces upto $73 \%$.

Fig. 22 to 24 shows maximum positive longitudinal bottom fiber stress results due to live load (IRC70R wheeled vehicle) on superstructure shows the variation for three different spans. Result shows, the maximum positive longitudinal top fiber stresses are maximum for single span $(50 \mathrm{~m})$, for two spans (25m each) it reduces upto $57 \%$ and for three spans $(16.67 \mathrm{~m}$ each) it reduces upto $73 \%$. Also the maximum negative longitudinal bottom fiber stresses are maximum for single span $(50 \mathrm{~m})$, for two spans $(25 \mathrm{~m}$ each) it reduces upto $57 \%$ and for three spans $(16.67 \mathrm{~m}$ each) it reduces upto $73 \%$.

Table -5 Maximum positive and negative BM and SF due to IRC70R wheeled vehicle load for three different spans

\begin{tabular}{|l|l|l|l|l|l|}
\hline $\begin{array}{l}\text { Sr. } \\
\text { No } \\
\cdot\end{array}$ & $\begin{array}{l}\text { Bridg } \\
\text { e } \\
\text { spans }\end{array}$ & $\begin{array}{l}\text { Max. } \\
\text { positi } \\
\text { ve } \\
\text { BM } \\
\text { in } \\
\text { kNm }\end{array}$ & $\begin{array}{l}\text { Max. } \\
\text { Negative } \\
\text { BM in } \\
\text { kNm }\end{array}$ & $\begin{array}{l}\text { Max. } \\
\text { positive } \\
\text { SF in } \\
\text { kN }\end{array}$ & $\begin{array}{l}\text { Max. } \\
\text { negati } \\
\text { ve } \\
\text { SF in } \\
\text { kN }\end{array}$ \\
\hline 1 & $\begin{array}{l}\text { Single } \\
\text { Span }\end{array}$ & 11240 & -16371 & 2291 & -2291 \\
\hline 2 & $\begin{array}{l}\text { Two } \\
\text { Span }\end{array}$ & 4874 & -7564 & 1903 & -1903 \\
\hline 3 & $\begin{array}{l}\text { Three } \\
\text { Span }\end{array}$ & 3074 & -4415 & 1546 & -1603 \\
\hline
\end{tabular}

Table -6 Maximum Axial force due to IRC70R for three different spans

\begin{tabular}{|l|l|l|}
\hline Sr.No. & Bridge spans & $\begin{array}{l}\text { Max.Axial force in } \\
\text { kN }\end{array}$ \\
\hline 1 & Single Span & -835 \\
\hline 2 & Two Span & -447 \\
\hline 3 & Three Span & -289 \\
\hline
\end{tabular}

Table -7 Max. positive and negative longitudinal stress at top fibre and bottom fibre of deck slab due to IRC70R truck vehicle load for three different spans

\begin{tabular}{|c|c|c|c|c|}
\hline $\begin{array}{l}\text { Bridg } \\
\text { e } \\
\text { spans }\end{array}$ & $\begin{array}{l}\text { Max. } \\
\text { positive } \\
\text { longitudi } \\
\text { nal } \\
\text { stresses } \\
\text { at top } \\
\text { fibre of } \\
\text { deck } \\
\text { slab in } \\
\mathrm{kN} / \mathrm{m}^{2}\end{array}$ & $\begin{array}{l}\text { Max. } \\
\text { negative } \\
\text { longitudi } \\
\text { nal } \\
\text { stresses } \\
\text { at top } \\
\text { fibre of } \\
\text { deck } \\
\text { slab in } \\
\mathbf{k N} / \mathrm{m}^{2}\end{array}$ & $\begin{array}{l}\text { Max. } \\
\text { positive } \\
\text { longitudi } \\
\text { nal } \\
\text { stresses } \\
\text { at } \\
\text { bottom } \\
\text { fibre } \\
\text { of deck } \\
\text { slab in } \\
\mathbf{k N} / \mathrm{m}^{2}\end{array}$ & $\begin{array}{l}\text { Max. } \\
\text { negative } \\
\text { longitud } \\
\text { inal } \\
\text { stresses } \\
\text { at } \\
\text { bottom } \\
\text { fibre } \\
\text { of deck } \\
\text { slab } \\
\text { inkN/m } 2 \\
\end{array}$ \\
\hline $\begin{array}{l}\text { Single } \\
\text { Span }\end{array}$ & 9910 & -7153 & 120311 & -178553 \\
\hline $\begin{array}{l}\text { Two } \\
\text { Span }\end{array}$ & 4584 & -3109 & 52131 & -82470 \\
\hline $\begin{array}{l}\text { Three } \\
\text { Span }\end{array}$ & 2670 & -1931 & 33074 & -48180 \\
\hline
\end{tabular}

\section{CONCLUSION}

- The bending moment in Integral Bridge can be reduced drastically by increasing number of spans. Converting an Integral Bridge into two spans results in reduction of BM upto $75 \%$ for DL and $57 \%$ for LL whereas a three span bridge results in $88 \%$ reduction for DL and $73 \%$ for LL and

- From Bending moment consideration a two span Integral Bridge shall be preferred

- The Shear force values for an Integral Bridge can be reduced drastically by increasing number of spans. Converting an Integral Bridge into two spans result in reduction $\mathrm{SF} 50 \%$ for DL and $17 \%$ for LL, loads ,whereas a three span bridge results in $66 \%$ reduction for DL and $33 \%$ for LL

- The Longitudinal extreme fiber stresses for a superstructure of an Integral Bridge can be reduced drastically by increasing number of spans. Converting an Integral Bridge into two spans result in reduction longitudinal extreme fiber stresses $75 \%$ for DL and $55 \%$ for LL, loads, whereas a three span bridge results in $89 \%$ reduction for DL and $73 \%$ for $\mathrm{LL}$

- From longitudinal extreme fiber stresses consideration a two span Integral Bridge shall be preferred

\section{REFERENCES}

[1]. Vasant C. Mistry(2005) "Integral Abutment and Jointless Bridges", IAJB

[2]. Murat Dicleli (2000)“'Simplified model for ComputerAided Analysis of Integral Bridges

[3]. Bhavik Rameshchandra Shah(2007) “3D Finite Element Analysis of Integral Abutment Bridges subjected to thermal loading"

[4]. Anssi Laaksonen "Structural behavior of long concrete bridges” Julkaisu 978, Publication 978. 


\section{BIOGRAPHIES}

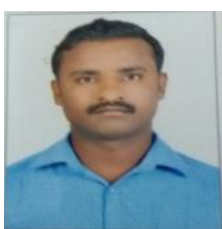

Prof. M. P. Bastwadkar, B.E.(Civil), M. Tech.(Structures),LMISTE. Working as a Asst. Professor at JSPM's Imperial College of Engineering and Research Wagholi, Pune ,Maharshtra, India

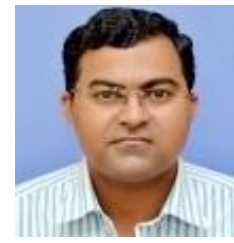

Prof. S. S. Manekari, B.E.(Civil), M.E.(Structures), LMISSE, LMISTE. Working as a Asst. Professor at JSPM's Imperial College of Engineering and Research Wagholi Pune ,Maharshtra, India 